JIIA, VOLUME 8 No. 1, FEBRUARI 2020

\title{
PENGARUH KUALITAS PELAYANAN, KUALITAS PRODUK, DAN PERSEPSI HARGA TERHADAP KEPUASAN KONSUMEN SUSU SEGAR MOO DI KOTA BANDAR LAMPUNG
}

\author{
(The Influence of Service Quality, Product Quality, and Perception on the Satisfaction of Moo Fresh Milk \\ Consumers in Bandar Lampung City)
}

Intan Paramiarta Ningrum, Wuryaningsih Dwi Sayekti, Rabiatul Adawiyah

Jurusan Agribisnis, Fakultas Pertanian, Universitas Lampung, Jl. Prof. Dr. Soemantri Brodjonegoro No.1

Bandar Lampung 35141,e-mail: wuryaningsih.dwisayekti@fp.unila.ac.id

\begin{abstract}
This study aims to determine purchasing patterns, satisfaction levels, influence of service quality, product quality, and price perceptions of the satisfaction of Moo fresh milk consumers. The research was a survey method conducted at Chandra Department Store, Tanjung Karang. The research samples were recruited by using accidental sampling. There were 50 households of Moo fresh milk consumers, in which respondents of this study were housewives. Data collection was conducted in May-June 2018 and were analyzed by descriptive analysis, Customer Satisfaction Index Analysis (CSI), and verification analysis. The results of this study indicated that the most bought was 1-liter-package type. The volume of purchases of Moo fresh milk was mostly 1-3 litters per month with a frequency of purchases of 1-2 times per month. The score of Moo fresh milk consumer satisfaction was 80.43 percent, meaning that consumers were satisfied. Service quality and product quality had significant effects; while price perception had no significant effect on consumer's satisfaction of fresh milk Moo.
\end{abstract}

Key words: fresh milk, satisfaction, service quality

\section{PENDAHULUAN}

Susu merupakan salah satu pangan yang berasal dari hewani. Menurut Sekretariat Jendral Pertanian (2016), perkembangan konsumsi susu di Indonesia mengalami fluktuasi dalam lima tahun terakhir dan tergolong rendah. Perkembangan konsumsi susu segar di Indonesia mengalami penurunan yang cukup signifikan pada tahun 20122013 sebesar 37,5 persen dari 0,16 liter menjadi 0,10 liter dan terlihat stabil pada tahun 2015-2016 sebanyak 0,15 liter/kap/tahun.

Konsumsi susu yang rendah diakibatkan oleh beberapa faktor, yaitu produksi susu yang rendah dan distribusi susu yang kurang merata (Kadir 2017). Produksi susu nasional hanya bisa memenuhi sekitar 20 persen dari kebutuhan susu atau kurang lebih baru memenuhi 852.000 ton dari total kebutuhan nasional sebanyak 4.450 .000 ton per tahun. Distribusi yang tidak merata menyebabkan konsumsi susu antara kota besar dengan daerah pedesaan mengalami ketimpangan. Distribusi susu yang kurang merata menyebabkan rendahya konsumsi susu oleh masyarakat. Hal ini memperlihatkan bahwa masih besarnya peluang bisnis yang dapat dimanfaatkan dan merupakan tantangan bagi produsen susu untuk meningkatkan produksinya.
Susu dapat dikelompokkan ke dalam dua jenis produk yaitu susu segar dan olahan. Susu segar dan susu olahan merupakan sama-sama produk minuman sehat, tetapi kandungan gizinya memiliki perbedaan. Menurut Subroto (2008), susu segar dalam proses produksinya tidak ditambah bahan tambahan seperti air dan pewarna dimana secara umum kandungan nutrisinya masih lengkap seperti lemak, protein, karbohidrat, mineral, dan vitamin, sedangkan susu olahan sudah mendapatkan bahan tambahan dalam proses produksinya.

Menurut Dinas Peternakan dan Kesehatan Hewan Provinsi Lampung (2016), produksi susu di Provinsi Lampung sebanyak $669.332 \mathrm{~kg}$ per tahun. Salah satu penyumbang produksi susu di Provinsi Lampung adalah PT Great Giant Livestock. Perusahaan tersebut merupakan perusahaan agribisnis yang bergerak dalam industri peternakan sapi perah dan memproduksi susu segar. Perusahaan tersebut berlokasi di Kecamatan Terbanggi Besar, Kabupaten Lampung Tengah, Provinsi Lampung, dan memulai produksi susu pada tahun 2015 dengan merek Susu Segar Moo yang menggunakan proses teknologi pasteurisasi. Berbagai merek produk susu segar dengan teknologi pasteurisasi yang ada di pasar seperti susu segar dengan merek Greenfields, dan Diamond menyebabkan PT Great Giant Livestock 
perlu meningkatkan pemasarannya dengan baik. Hal ini menyebabkan persaingan antar perusahaan produk sejenis menjadi sangat ketat. Oleh karena itu, perusahaan perlu mengetahui informasi terkait kepuasan konsumen dan pola pembelian susu untuk meningkatkan pemasarannya dalam memenangkan persaingan.

Menurut Harper, Deaton, dan Driskel (1986), pola konsumsi pangan menggambarkan suatu jumlah, jenis dan frekuensi bahan makanan yang dikonsumsi seseorang dan menjadi suatu ciri khas pada suatu kelompok masyarakat. Pola konsumsi pangan dalam penelitian ini adalah pola pembelian. Kepuasan konsumen berhubungan dengan pola pembelian terhadap suatu produk. Tingkat kepuasan konsumen akan menentukan pemilihan suatu produk melalui proses keputusan pembelian, sehingga terlihat pola pembelian seseorang terhadap suatu produk.

Kepuasan konsumen merupakan tingkat perasaan seseorang yang dirasakan dari suatu manfaat yang diberikan oleh produk dirasa sesuai dengan apa yang diharapkannya (Rustanti 2015). Beberapa faktor-faktor yang mempengaruhi kepuasan konsumen yaitu kualitas pelayanan, kualitas produk, dan harga. Kualitas pelayanan mempengaruhi kepuasan konsumen karena dalam pembelian terjadi interaksi antar konsumen dengan pihak perusahaan baik secara langsung maupun tidak langsung. Kualitas produk mempengaruhi kepuasan konsumen dan sangat diperhatikan oleh konsumen dalam memilih serta mengonsumsi suatu produk. Hal ini karena, setiap konsumen menginginkan kualitas terbaik dari produk yang dibelinya.

Harga produk juga mempengaruhi kepuasan konsumen. Persepsi konsumen terhadap mahal atau murahnya harga suatu produk bersifat relatif, maka pihak perusahaan sebagai produsen harus memantau harga yang ditetapkan oleh pesaing khususnya produk sejenis, agar harga yang ditawarkan kepada konsumen terjangkau dalam arti tidak terlalu tinggi dibandingkan dengan produk pesaing. Tujuan penelitian ini adalah mengetahui pola pembelian, tingkat kepuasan konsumen, dan pengaruh kualitas pelayanan, kualitas produk, dan persepsi harga terhadap kepuasan konsumen Susu Segar Moo di Kota Bandar Lampung.

\section{METODE PENELITIAN}

Penelitian ini dilakukan menggunakan metode survai di Kota Bandar Lampung. Lokasi dipilih secara sengaja (purposive) di Chandra Departement Store Tanjung Karang dengan pertimbangan Chandra Departement Store Tanjung Karang merupakan salah satu tempat pemasaran Susu Segar Moo yang penjualannya paling banyak dibandingkan dengan supermarket lainnya yang ada di Kota Bandar Lampung.

Penentuan sampel dilakukan dengan metode accidental sampling yaitu metode penentuan sampel secara kebetulan. Menurut Martono (2012), jumlah sampel penelitian minimum yang dapat diterima sebanyak 30 sampel dan ditambahkan sampel cadangan dengan asumsi bahwa semakin banyak sampel, maka semakin representative. Jumlah sampel dalam penelitian ini yaitu 50 rumah tangga. Responden dalam penelitian ini adalah ibu rumah tangga atau anggota keluarga lain dengan kriteria yaitu berusia 17 tahun ke atas, membeli dan mengonsumsi Susu Segar Moo, dan telah membeli dan mengonsumsi Susu Segar Moo minimal dua kali dalam satu bulan. Pengumpulan data penelitian dilakukan pada bulan Mei sampai Juni 2018.

Data yang dikumpulkan dalam penelitian ini berupa data primer dan sekunder. Data primer mencakup data terkait dengan pola pembelian, tingkat kepuasan konsumen, kualitas pelayanan, kualiatas produk, dan persepsi harga Susu Segar Moo. Data primer tersebut diperoleh melalui wawancara dengan menggunakan kuesioner. Data sekunder mencakup antara lain data produksi susu sapi di Provinsi Lampung yang bersumber dari Dinas Peternakan dan Kesehatan Hewan Provinsi Lampung.

Kuesioner penelitian lebih dulu diuji menggunakan uji validitas dan reliabilitasnya. Kuesioner penelitian yang diuji validitas dan reliabilitas adalah kuesioner mengenai tingkat kepuasan konsumen, kualitas pelayanan, kualitas produk, dan persepsi harga. Menurut Sufren dan Natanael (2013), kuesioner dikatakan valid, apabila nilai corrected item dari total korelasi bernilai diatas 0,2). Uji reliabilitas dengan Cronbach's Alpha dalam kuesioner dapat dikatakan reliabel jika nilai alpha $(\alpha)>0.60$ (Arikunto 2006). Hasil uji validitas dan relabilitas kuesioner dapat dilihat pada Tabel 1 dan 2 . 
Tabel 1. Hasil uji validitas dan reliabilitas tingkat kepentingan dan tingkat kinerja atribut kepuasan Susu Segar Moo

\begin{tabular}{lcr}
\hline $\begin{array}{c}\text { Atribut Susu Segar } \\
\text { Moo }\end{array}$ & $\begin{array}{c}\text { Tingkat } \\
\text { Kepentingan } \\
\text { Susu Segar Moo }\end{array}$ & $\begin{array}{c}\text { Tingkat Kinerja } \\
\text { Susu Segar Moo }\end{array}$ \\
\cline { 2 - 3 } Corrected Item-Total Correlation \\
\hline Rasa & 0,529 & 0,427 \\
Aroma & 0,524 & 0,507 \\
Desain kemasan & 0,369 & 0,500 \\
Jaminan halal & 0,321 & 0,483 \\
Izin BPOM & 0,310 & 0,511 \\
Tanggal kadaluarsa & 0,452 & 0,462 \\
Harga & 0,549 & 0,357 \\
Promosi & 0,563 & 0,380 \\
Kandungan gizi & 0,490 & 0,602 \\
\hline Cronbach's Alpha tingkat kepentingan Susu Segar Moo 0,764 \\
\hline \multicolumn{2}{l}{ Cronbach's Alpha tingkat kinerja Susu Segar Moo 0,768 } \\
\hline
\end{tabular}

Tabel 2. Hasil uji validitas dan reliabilitas variabel kualitas pelayanan, kualitas produk, dan persepsi harga Susu Segar Moo.

\begin{tabular}{|c|c|c|c|}
\hline No & Variabel Indikator & $\begin{array}{c}\text { Corrected } \\
\text { Item-Total } \\
\text { Correlation }\end{array}$ & $\begin{array}{l}\text { Cronbach's } \\
\text { Alpha }\end{array}$ \\
\hline \multirow[t]{9}{*}{1} & Kualitas pelayanan & & \\
\hline & Kebersihan tempat & 0,317 & 0,666 \\
\hline & Ketersediaan chiller & 0,428 & \\
\hline & Kerapian tempat & 0,473 & \\
\hline & Ketepatan pelayanan & 0,338 & \\
\hline & Kecepatan dan & 0,382 & \\
\hline & ketanggapan pelayanan & & \\
\hline & Keramahan petugas & 0,413 & \\
\hline & Mudah dihubungi & 0,364 & \\
\hline \multirow[t]{6}{*}{2} & Kualitas produk & & \\
\hline & Rasa & 0,431 & 0,653 \\
\hline & Kemasan & 0,303 & \\
\hline & Tampilan & 0,439 & \\
\hline & Higienis & 0,493 & \\
\hline & Merek & 0,393 & \\
\hline \multirow[t]{6}{*}{3} & Persepsi harga & & \\
\hline & Keterjangkauan harga & 0,566 & 0,624 \\
\hline & $\begin{array}{l}\text { Persaingan harga } \\
\text { produk sejenis }\end{array}$ & 0,584 & \\
\hline & Asumsi harga dan & 0,454 & \\
\hline & kualitas produk & & \\
\hline & Harga diskon & 0,000 & \\
\hline
\end{tabular}

Berdasarkan Tabel 1, nilai corrected item-total correlation dari masing-masing atribut Susu Segar Moo di atas 0,2 dan nilai Cronbach's alpha di atas 0,6 . Hal ini menunjukkan bahwa pertanyaan yang diajukan valid dan reliabel sehingga dapat digunakan untuk pengumpulan data.

Berdasarkan Tabel 2, variabel kualitas pelayanan, kualitas produk dan persepsi harga mempunyai nilai corrected item-total correlation dari masingmasing indikator yaitu di atas 0,2 dan nilai cronbach's alpha di atas 0,6. Hal ini menunjukkan bahwa pertanyaan yang diajukan valid dan reliabel sehingga dapat digunakan untuk pengumpulan data. Namun, terdapat satu indikator pertanyaan yang tidak valid yaitu pertanyaan mengenai harga diskon karena memiliki nilai corrected item-total correlation di bawah 0,2 .

Tujuan pertama mengenai pola pembelian Susu Segar Moo dianalisis menggunakan analisis deskriptif. Pola pembelian Susu Segar Moo dilihat dari jenis susu yang dibeli, volume pembelian, frekuensi pembelian, anggota keluarga yang sering membeli dan dominan mengonsumsi susu, cara mengonsumsi susu, dan alasan mengonsumsi susu.

Tujuan ke dua mengenai tingkat kepuasan konsumen Susu Segar Moo dianalisis menggunakan Customer Satisfaction Index Analysis (CSI). Tahapan pengukuran CSI adalah sebegai berikut:

(1) Menghitung Weighting Factors (WF), yaitu mengubah nilai rata-rata kepentingan menjadi angka persentase dari total rata-rata tingkat kinerja atribut yang diuji.

(2) Menghitung Weighted Score (WS), yaitu menghitung perkalian antara nilai rata-rata tingkat kinerja masing-masing atribut dengan Weighting Factors masing-masing atribut.

(3) Menghitung Weighted Total (WT), yaitu menjumlahkan Weighted Score dari semua atribut.

(4) Menghitung Satisfaction Index, yaitu Weighted Total dibagi dengan skala maksimum dan dikali dengan seratus persen, di mana skala maksimum yang digunakan yaitu lima.

Tujuan ketiga mengenai pengaruh kualitas pelayanan, kualitas produk, dan persepsi harga terhadap kepuasan konsumen Susu Segar Moo di Kota Bandar Lampung dianalisis menggunakan analisis verifikatif dengan menggunakan regresi linier berganda. Faktor-faktor yang diduga mempengaruhi kepuasan konsumen adalah kualitas pelayanan (X1), kualitas produk (X2), dan persepsi harga $\left(\mathrm{X}_{3}\right)$. Sebelum dilakukan analisis regresi berganda data penelitian yang berupa skala likert (data ordinal) diubah menjadi data interval menggunakan metode successive interval (MSI). Model persamaan fungsi kepuasan konsumen sebagai berikut.

$\mathrm{Y}=\mathrm{b} 0+\mathrm{b} 1 \mathrm{X} 1+\mathrm{b} 2 \mathrm{X} 2+\mathrm{b} 3 \mathrm{X} 3+\mathrm{e}$

Keterangan :

$\mathrm{Y}=$ Kepuasan konsumen

b0 = Intersep 


$$
\begin{array}{ll}
\mathrm{b} 1-\mathrm{b} 3 & =\text { Koefisien regresi } \\
\mathrm{X} 1 & =\text { Kualitas pelayanan } \\
\mathrm{X} 2 & =\text { Kualitas produk } \\
\mathrm{X} 3 & =\text { Presepsi harga } \\
\mathrm{e} & =\text { Standard error }
\end{array}
$$

\section{HASIL DAN PEMBAHASAN}

\section{Karakteristik Responden}

Karakteristik responden dalam penelitian ini diuraikan berdasarkan jenis kelamin, usia, tingkat pendidikan terakhir, jenis pekerjaan, pendapatan rumah tangga, dan pengeluaran untuk susu. Jumlah responden penelitian sebanyak 50 rumah tangga konsumen Susu Segar Moo yang keseluruhan berjenis kelamin perempuan dengan rata-rata usia yaitu 35,5 tahun di mana sebesar 50 persen berada pada kelompok usia 36-50 tahun. Jika dilihat dari tingkat pendidikan terakhir responden, maka responden paling banyak lulusan perguruan tinggi (D3, S1, dan seterusnya) sebanyak 27 orang (54\%). Jenis pekerjaan responden didominasi oleh jenis pekerjaan lainnya (56\%) dengan jenis perkerjaan sebagai ibu rumah tangga sebanyak 26 orang, pekerja laundry 1 orang, dan pramuniaga 1 orang. Pendapatan rumah tangga rata-rata sebesar Rp4.912.000,00 per bulan di mana sebesar 80 persen berada pada golongan pendapatan sangat tinggi atau lebih besar dari Rp4.000.000,00 per bulan.

Susu yang dibeli oleh responden tidak hanya Susu Segar Moo, sebesar 74 persen responden membeli susu jenis lain. Susu jenis lain yang dibelii antara lain susu bubuk, UHT, dan susu kental manis. Pengeluaran untuk susu dikelompokkan menjadi pengeluaran Susu Segar Moo saja serta pengeluaran Susu Segar Moo dan susu jenis lain.

Berdasarkan hasil penelitian dari 50 rumah tangga terdapat 12 rumah tangga yang hanya mengonsumsi Susu Segar Moo saja. Rumah tangga yang hanya mengonsumsi Susu Segar Moo saja, pengeluarannya untuk susu yaitu berkisar antara Rp59.800,00-Rp209.300,00 dengan ratarata sebesar Rp113.650,00 per bulan. Rumah tangga yang mengonsumsi Susu Segar Moo saja pengeluaran untuk susu paling banyak yaitu pada rentang Rp59.800,00-Rp109.633,00 per bulan sebanyak 6 rumah tangga (50\%).

Berdasarkan hasil penelitian terdapat 38 rumah tangga yang mengonsumsi Susu Segar Moo dan susu jenis lain. Rumah tangga yang mengonsumsi Susu Segar Moo dan susu jenis lain, pengeluarannya untuk susu yaitu berkisar antara
Rp89.800,00-Rp349.700,00 dengan rata-rata sebesar Rp201.792,11 per bulan. Rumah tangga yang mengonsumsi Susu Segar Moo dan susu jenis lain pengeluaran untuk susu paling banyak yaitu pada rentang $\mathrm{Rp} 176.434,00-\mathrm{Rp} 263.066,00$ per bulan sebanyak 24 responden $(63,16 \%)$. Rumah tangga yang mengonsumsi Susu Segar Moo dan susu jenis lain mempunyai pengeluaran yang lebih besar dibandingkan dengan rumah tangga yang hanya mengonsumsi Susu Segar Moo saja. Hal ini disebabkan susu yang dikonsumsi tidak hanya Susu Segar Moo saja melainkan susu jenis lain sehingga mayoritas rumah tangga memiliki pengeluaran yang besar untuk susu per bulan.

\section{Pola Pembelian Susu Segar Moo}

Pola pembelian Susu Segar Moo dilihat dari jenis susu yang dibeli, volume pembelian, frekuensi pembelian, anggota keluarga yang sering membeli dan mengonsumsi susu, cara mengonsumsi susu, dan alasan mengonsumsi susu. Jenis Susu Segar Moo yang dibeli dalam penelitian ini dilihat dari varian ukuran kemasannya.

Mayoritas rumah tangga yaitu sebanyak 47 rumah tangga (94\%) membeli Susu Segar Moo ukuran satu liter. Volume pembelian dalam penelitian dilihat dari jumlah Susu Segar Moo yang dibeli dan diukur dalam satuan liter. Volume pembelian Susu Segar Moo oleh rumah tangga berkisar antara 1-7 liter dengan rata-rata 3 liter per bulan. Sebagian besar rumah tangga (80\%) melakukan pembelian sebanyak 1-3 liter per bulan. Frekuensi pembelian rata-rata 2 kali per bulan di mana sebagian besar konsumen (68\%) melakukan pembelian dengan frekuensi yaitu 1-2 kali per bulan. Hasil penelitian sejalan dengan penelitian Kabuli, Indriani, dan Situmorang (2018), yang menyatakan bahwa frekuensi rata-rata pembelian yoghurt oleh 48 orang konsumen di Bandar Lampung adalah sebanyak dua kali per orang per bulan.

Anggota keluarga yang sering melakukan pembelian adalah ibu (98\%) dan yang paling banyak mengonsumsi susu adalah anak-anak (58\%). Cara mengonsumsi susu oleh konsumen yaitu langsung diminum (80\%) dengan alasan mengonsumsi untuk kesehatan $(56 \%)$.

\section{Tingkat Kepuasan Konsumen Susu Segar Moo}

Hasil penelitian ini menunjukkan bahwa skor ratarata dari 9 atribut kepentingan mencapai 3,96. Atribut Izin BPOM mendapatkan skor rata-rata 
tertinggi sebesar 4,54 dan atribut promosi mempunyai skor rata-rata terendah sebesar 3,38. Atribut izin BPOM mendapatkan skor rata-rata tertinggi disebabkan atribut tersebut dinilai penting oleh konsumen karena produk yang telah mempunyai izin BPOM berarti aman untuk dikonsumsi. Atribut promosi mendapatkan skor rata-rata terendah disebabkan promosi yang dilakukan tidak mudah mempengaruhi atau menarik minat konsumen untuk membeli Susu Segar Moo. Skor rata-rata dari 9 atribut kinerja mencapai 3,99. Atribut jaminan halal mendapatkan skor rata-rata tertinggi sebesar 4,48 dan atribut desain kemasan memiliki skor rata-rata terendah sebesar 3,12. Atribut jaminan halal mendapatkan skor rata-rata tertinggi disebabkan atribut tersebut dinilai baik oleh konsumen. Atribut jaminan halal sudah tertera dan jelas pada label kemasan, di mana Susu Segar Moo merupakan produk minuman sehingga jaminan halal harus jelas. Atribut desain kemasan mendapatkan skor rata-rata terendah disebabkan desain kemasan produk tersebut dinilai kurang menarik oleh konsumen. Hal ini dikarenakan warna pada label kemasan hanya berwarna putih, hitam, dan biru. Gambar serta tulisan pada label yang terlihat biasa saja. Hasil perhitungan CSI Susu Segar Moo dapat dilihat pada Tabel 3.

Berdasarkan data Tabel 3, nilai CSI produk Susu Segar Moo berada pada rentang skala 0,61 - 0,80 yang berarti bahwa kepuasan konsumen Susu Segar Moo di Kota Bandar Lampung telah dapat dicapai sebesar 80,43 persen. Hal ini sejalan dengan penelitian Putri, Prasmatiwi, dan Adawiyah (2015), yang menyatakan bahwa kepuasan konsumen susu bubuk di Kota Bandar Lampung sudah merasa puas dengan nilai CSI sebesar 76,54 persen. Hasil penelitian ini mendapatkan nilai CSI lebih tinggi dari nilai CSI susu bubuk di Kota Bandar Lampung. Hal ini menunjukkan bahwa kepentingan atribut dan kinerja atribut Susu Segar Moo telah berfungsi dengan baik sehingga memberikan kepuasan terhadap konsumen dengan tingkat kepuasan yang lebih tinggi yaitu sebesar 80,43 persen.

\section{Analisis Pengaruh Kualitas Pelayanan, Kualitas Produk, dan Persepsi Harga Terhadap Kepuasan Konsumen Susu Segar Moo}

Kualitas pelayanan merupakan tingkat keunggulan yang diharapkan untuk memenuhi keinginan konsumen. Kualitas pelayanan dalam penelitian ini diukur menggunakan tujuh indikator yaitu, kebersihan tempat, ketersediaan chiller, kerapian
Tabel 3. Perhitungan Customer Satisfaction Index (CSI) Susu Segar Moo

\begin{tabular}{lrrrr}
\hline Atribut Produk & RSP & \multicolumn{1}{c}{ WF } & \multicolumn{1}{c}{ RSK } & \multicolumn{1}{l}{ WS } \\
\hline Rasa & 4,02 & 0,11 & 4,04 & 0,46 \\
Aroma & 4,12 & 0,12 & 4,06 & 0,47 \\
Desain Kemasan & 3,48 & 0,10 & 3,12 & 0,30 \\
Jaminan Halal & 4,04 & 0,11 & 4,48 & 0,51 \\
Izin BPOM & 4,54 & 0,13 & 4,42 & 0,56 \\
Tanggal Kadaluarsa & 4,46 & 0,13 & 4,42 & 0,55 \\
Harga & 3,72 & 0,10 & 3,18 & 0,33 \\
Promosi & 3,38 & 0,09 & 3,76 & 0,36 \\
Kandungan Gizi & 3,90 & 0,11 & 4,40 & 0,48 \\
\hline WT & 35,66 & 1,00 & 35,88 & 4,02 \\
CSI & & & & 80,43 \\
\hline
\end{tabular}

Keterangan :

$\mathrm{RSP}=$ Rata-rata skor kepentingan

$\mathrm{WF}=$ Weighting Factor

$\mathrm{RSK}=$ Rata-rata skor kinerja

$\mathrm{WS}=$ Weighted Score

$\mathrm{WT}=$ Weighted Total

tempat, ketepatan pelayanan, kecepatan dan ketanggapan pelayanan, keramahan petugas (SPG), dan mudah dihubungi yang disajikan pada Tabel 4 . Berdasarkan data Tabel 4, memperlihatkan sebagian besar konsumen menjawab dengan skor 4 yaitu baik. Setiap kategori memiliki interval yaitu 280 dan jumlah skor yang diperoleh yaitu 1.384 yang kemudian dikategorikan melalui garis kategorisasi seperti pada Gambar 1. Berdasarkan Gambar 1 terlihat bahwa skor maksimum yang dicapai sebesar 1.750, artinya ketercapaian penilaian konsumen terhadap kualitas pelayanan Susu Segar Moo mencapai 79,08 persen. Artinya, penilaian konsumen terhadap kualitas pelayanan adalah baik.

Kualitas produk merupakan karakteristik suatu barang atau jasa yang berpengaruh pada kemampuannya untuk memuaskan kebutuhan konsumen. Kualitas produk dalam penelitian ini diukur menggunakan lima indikator yaitu, rasa, tampilan, kemasan, higienis, dan merek yang disajikan pada Tabel 5. Berdasarkan data Tabel 5, memperlihatkan sebagian besar konsumen menjawab dengan skor 4 yaitu baik. Setiap kategori memiliki interval yaitu 200 dan jumlah skor yang diperoleh yaitu 955 yang kemudian dikategorikan melalui garis kategorisasi seperti pada Gambar 2. 
Tabel 4. Penilaian konsumen terhadap kualitas pelayanan Susu Segar Moo

\begin{tabular}{|c|c|c|c|c|c|c|}
\hline \multirow[t]{2}{*}{ Indikator } & \multicolumn{5}{|c|}{$\begin{array}{c}\text { Skor dan Jumlah } \\
\text { Konsumen }\end{array}$} & \multirow{2}{*}{$\begin{array}{c}\sum \text { Skor (Skor } \\
\text { x jumlah } \\
\text { konsumen) }\end{array}$} \\
\hline & 1 & 2 & 3 & 4 & 5 & \\
\hline $\begin{array}{l}\text { - Kebersihan } \\
\text { tempat }\end{array}$ & 0 & 5 & 1 & 38 & 6 & 195 \\
\hline $\begin{array}{l}\text { - Ketersediaan } \\
\text { chiller }\end{array}$ & 0 & 0 & 3 & 36 & 11 & 208 \\
\hline $\begin{array}{l}\text { - Kerapian } \\
\text { tempat } \\
\text { penjualan }\end{array}$ & 0 & 0 & 12 & 31 & 7 & 195 \\
\hline $\begin{array}{l}\text { - Ketepatan } \\
\text { pelayanan } \\
\text { penjualan }\end{array}$ & 0 & 0 & 12 & 27 & 11 & 199 \\
\hline $\begin{array}{l}\text { - Kecepatan } \\
\text { dan } \\
\text { ketanggapan } \\
\text { pelayanan }\end{array}$ & 0 & 0 & 12 & 30 & 8 & 196 \\
\hline $\begin{array}{l}\text { - Keramahan } \\
\text { petugas (SPG) }\end{array}$ & 0 & 0 & 5 & 19 & 26 & 221 \\
\hline $\begin{array}{l}\text { - Mudah } \\
\text { dihubungi }\end{array}$ & 0 & 1 & 29 & 19 & 1 & 170 \\
\hline & & & & & & 1.384 \\
\hline
\end{tabular}

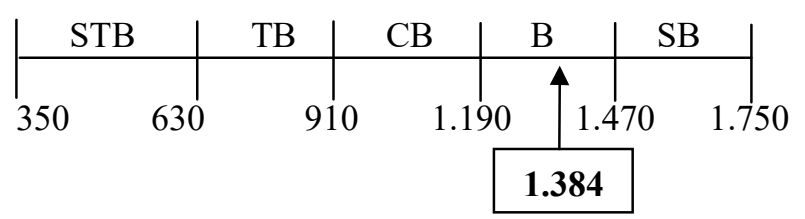

Gambar 1. Garis kategorisasi kualitas pelayanan Susu Segar Moo

Gambar 2 memperlihatkan bahwa skor maksimum yang dicapai sebesar 1.250, artinya ketercapaian penilaian konsumen terhadap kualitas produk tersebut mencapai 76,40 persen. Persepsi harga merupakan penilaian konsumen terhadap harga produk. Harga diukur menggunakan tiga indikator yaitu, keterjangkauan harga, persaingan harga produk sejenis, asumsi harga dengan kualitas produk yang disajikan pada Tabel 6. Data pada Tabel 6, memperlihatkan sebagian besar konsumen menjawab dengan skor 4 yaitu baik. Setiap kategori memiliki interval yaitu 120 dan jumlah skor yang diperoleh yaitu 584 yang kemudian dikategorikan melalui garis kategorisasi seperti pada Gambar 3. Gambar 3 memperlihatkan bahwa skor maksimum yang dicapai sebesar 750 , artinya ketercapaian penilaian konsumen terhadap harga Susu Segar Moo mencapai 78 persen. Artinya, penilaian konsumen terhadap harga Susu Segar Moo adalah baik.
Tabel 5. Penilaian konsumen terhadap kualitas produk Susu Segar Moo

\begin{tabular}{|c|c|c|c|c|c|c|}
\hline \multirow[t]{2}{*}{ Indikator } & \multicolumn{5}{|c|}{$\begin{array}{c}\text { Skor dan Jumlah } \\
\text { Konsumen }\end{array}$} & \multirow{2}{*}{$\begin{array}{c}\sum \text { Skor (Skor } \\
\text { x jumlah } \\
\text { konsumen) }\end{array}$} \\
\hline & 1 & 2 & 3 & 4 & 5 & \\
\hline - Rasa & 0 & 2 & 14 & 24 & 10 & 192 \\
\hline - Kemasan & 1 & 18 & 16 & 15 & 0 & 145 \\
\hline - Tampilan & 0 & 1 & 16 & 24 & 9 & 191 \\
\hline - Higi & 0 & 0 & 2 & 16 & 32 & 230 \\
\hline - Mer & 0 & 0 & 15 & 23 & 12 & 197 \\
\hline \multicolumn{6}{|c|}{ Total Skor } & 955 \\
\hline
\end{tabular}

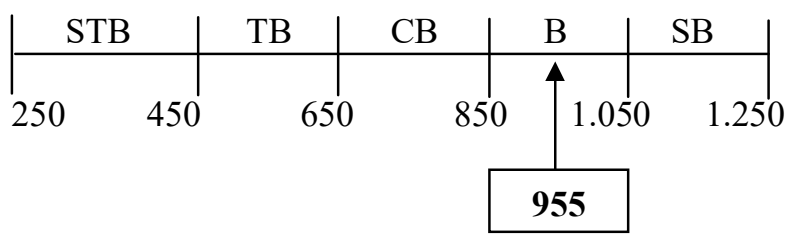

Gambar 2. Garis kategorisasi kualitas produk Susu Segar Moo

Faktor-faktor yang diduga mempengaruhi kepuasan dalam penelitian ini adalah kualitas pelayanan, kualitas produk, dan persepsi harga. Uji asumsi klasik dilakukan untuk mengetahui atau menguji heterokedastisitas dan multikolinieritas. Uji heteroskedastisitas ini diuji dengan menggunakan scatter-plots. Hasil uji heterokedastisitas dalam penelitian ini adalah tidak terjadi heterokedastisitas.

Menurut Ghozali (2009), suatu model regersi terdapat multikolinieritas apabila nilai Variance Inflation Factor (VIF) $>10$ dan nilai tolerance tidak boleh lebih kecil dari 0,1 sedangkan apabila nilai VIF $<10$ dan nilai tolerance lebih besar dari 0,1 maka tidak terdapat gejala multikolinieritas.

Tabel 6. Penilaian konsumen terhadap harga produk Susu Segar Moo

\begin{tabular}{|c|c|c|c|c|c|c|}
\hline \multirow{2}{*}{ Indikator } & \multicolumn{5}{|c|}{$\begin{array}{c}\text { Skor dan Jumlah } \\
\text { Konsumen }\end{array}$} & \multirow{2}{*}{$\begin{array}{c}\sum \text { Skor } \\
\text { (Skor x } \\
\text { jumlah } \\
\text { konsumen) }\end{array}$} \\
\hline & 1 & 2 & 3 & 4 & 5 & \\
\hline \multirow{3}{*}{$\begin{array}{l}\text { - Keterjangkauan } \\
\text { harga } \\
\text { - Persaingan } \\
\text { harga produk } \\
\text { sejenis } \\
\text { - Asumsi harga } \\
\text { dan kualitas } \\
\text { produk }\end{array}$} & 0 & 0 & 2 & 32 & 16 & 214 \\
\hline & 0 & 2 & 39 & 9 & 0 & 157 \\
\hline & 0 & 0 & 4 & 29 & 17 & 213 \\
\hline \multicolumn{6}{|c|}{ Total Skor } & 584 \\
\hline
\end{tabular}




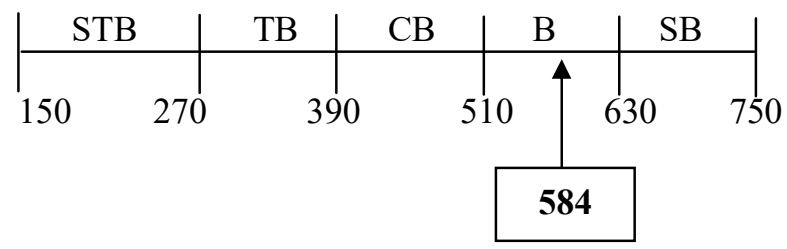

Gambar 3. Garis kategorisasi harga Susu Segar Moo

Hasil dari uji multikolinieritas dalam penelitian ini setiap variabel memiliki nilai VIF kurang dari 10, sehingga tidak menunjukkan tidak adanya multikolinearitas.

Variabel yang digunakan dalam penelitian ini terdiri dari variabel bebas dan terikat. Variabel bebas dalam penelitian ini adalah kualitas pelayanan (X1), kualitas produk (X2), persepsi harga (X3), sedangkan variabel terikatnya adalah kepuasan konsumen (Y). Hasil uji regresi linier berganda kepuasan konsumen rumah tangga terhadap produk Susu Segar Moo oleh variabel bebas yang telah ditentukan dapat dilihat pada Tabel 7. Model fungsi kepuasan konsumen Susu Segar Moo tangga di Kota Bandar Lampung adalah sebagai berikut.

$\mathrm{Y}=5780,643+0,357 \mathrm{X} 1+0,476 \mathrm{X} 2+0,142 \mathrm{X} 3$

Berdasarkan data pada Tabel 7, diketahui bahwa nilai $R$-squared pada model persamaan kepuasan konsumen Susu Segar Moo adalah sebesar 0,180 dan nilai Adjusted R-Squared sebesar 0,126. Hal ini berarti bahwa kepuasan konsumen Susu Segar Moo dapat dijelaskan berdasarkan model dengan variabel-variabel sebesar 12,60 persen dan sisanya sebesar 87,40 persen dijelaskan oleh variabel lain di luar model penelitian. Menurut Lupiyoadi (2001), kepuasan konsumen dipengaruhi oleh beberapa faktor yaitu kualitas produk, kualitas pelayanan, emosi, harga, biaya, dan promosi. Nilai Adjusted $R$-Squared terbilang kecil karena variabel penelitian yang digunakan hanya kualitas pelayanan, kualitas produk, dan persepsi harga.. Hal ini memperlihatkan bahwa terdapat beberapa faktor yang tidak digunakan dalam penelitian seperti emosi, biaya dan promosi sehingga menyebabkan nilai Adjusted R-Squared kecil atau hanya sebesar 12,60 persen. Hipotesis yang diajukan dalam penelitian ini adalah diduga kualitas pelayanan, kualitas produk, dan persepsi harga berpengaruh nyata terhadap kepuasan konsumen Susu Segar Moo. Nilai F hitung dalam penelitian ini sebesar 3,362 dengan nilai probabilitasnya sebesar 0,027 .
Tabel 8. Hasil analisis regresi berganda kepuasan konsumen Susu Segar Moo di Kota Bandar Lampung

\begin{tabular}{lrrr}
\hline \multicolumn{1}{c}{ Variabel } & \multicolumn{1}{c}{$\begin{array}{c}\text { Koefisien } \\
\text { Regresi } \\
\text { (B) }\end{array}$} & t & Probabilitas \\
\hline Konstanta (C) & 5780,643 & 1,184 & 0,243 \\
Kualitas Pelayanan & $* * 0,357$ & 2,097 & 0,042 \\
Kualitas Produk & $* * 0,476$ & 2,064 & 0,045 \\
Persepsi Harga & 0,142 & 0,465 & 0,644 \\
\hline F-hitung & 3,362 & & 0,027 \\
R-squared & 0,180 & & \\
Adjusted R-Squared & 0,126 & & \\
\hline
\end{tabular}

Keterangan :

* : Nyata pada taraf kepercayaan 90 persen

** : Nyata pada taraf kepercayaan 95 persen

*** : Nyata pada taraf kepercayaan 99 persen

Hal ini menjelaskan bahwa variabel kualitas pelayanan (X1), kualitas produk (X2), persepsi harga (X3), secara bersama-sama berpengaruh nyata terhadap kepuasan konsumen Susu Segar Moo dengan tingkat kepercayaan sebesar 95 persen.

Terdapat dua variabel bebas yang berpengaruh nyata terhadap kepuasan konsumen Susu Segar Moo yaitu kualitas pelayanan dan kualitas produk. Variabel kualitas pelayanan berpengaruh nyata dengan nilai t hitung sebesar 2,097 dan probabilitas sebesar 0,042 serta berpengaruh positif. Kualitas produk berpengaruh nyata terhadap kepuasan konsumen dengan nilai t hitung sebesar 2,064 dan probabilitas sebesar 0,045 serta berpengaruh positif. Artinya semakin tinggi kualitas produk Susu Segar Moo akan semakin tinggi tingkat kepuasan konsumen terhadap produk tersebut. Hal ini sejalan dengan penelitian Windarti dan Ibrahim (2017), pada produk Donat Madu yang menyatakan bahwa kualitas produk berpengaruh nyata terhadap kepuasan konsumen. Hal ini mengartikan, semakin tinggi kualitas produk maka dapat meningkatkan kepuasan konsumen.

Variabel yang tidak berpengaruh nyata dalam penelitian ini adalah persepsi harga. Persepsi harga tidak berpengaruh nyata terhadap kepuasan konsumen dengan nilai t hitung sebesar 0,465 dan probabilitas sebesar 0,644. Hasil penelitian ini tidak sejalan dengan penelitian Mountung, Sepang, dan Andare (2015), yang menyatakan bahwa variabel persepsi harga di Restoran Kawan Baru berpengaruh nyata terhadap kepuasan konsumen. 


\section{KESIMPULAN}

Volume kemasan Susu Segar Moo yang banyak dikonsumsi adalah ukuran satu liter, jumlah pembelian paling banyak adalah $1-3$ liter per bulan dengan frekuensi pembelian yaitu $1-2$ kali per bulan, anggota keluarga yang sering membeli susu adalah ibu dan yang paling banyak mengonsumsi susu adalah anak-anak, cara mengonsumsi susu yaitu langsung diminum dengan alasan mengonsumsi yaitu untuk kesehatan. Nilai CSI Susu Segar Moo di Kota Bandar Lampung sebesar 80,43 persen, hal ini menunjukkan bahwa konsumen Susu Segar Moo di Kota Bandar Lampung merasa puas. Secara bersama-sama variabel kualitas pelayanan, kualitas produk, dan persepsi harga berpengaruh nyata terhadap kepuasan konsumen Susu Segar Moo.

\section{DAFTAR PUSTAKA}

Arikunto S. 2006. Prosedur Penelitian Suatu Pendekatan Praktik. PT. Rineka Cipta. Jakarta.

Dinas Peternakan dan Kesehatan Hewan Provinsi Lampung. 2016. 2016 Provinsi Lampung Produksi Susu Kabupaten/Kota. Dinas Peternakan dan Kesehatan Hewan Provinsi Lampung. Bandar Lampung.

Dinas Peternakan dan Kesehatan Hewan Provinsi Lampung. Bandar Lampung.

Ghozali. 2009. Aplikasi Analisis Multivariate Dengan Program SPSS. Edisi ke-4. Universitas Diponegoro. Semarang.

Harper LJ, Deaton BJ dan Driskel JA. 1986. Pangan, Gizi, dan Pertanian. Diterjemahkan oleh Suhardjo UI Press. Jakarta.

Kabuli KK, Indriani Y dan Situmorang S. 2018. Analisis pengetahuan dan sikap konsumen dalam membeli yoghurt di Bandar Lampung. JIIA, 6(2): 196-204. http://jurnal.fp.unila. ac.id/index.php/JIA/article/view/2786/2332

[10 Desember 2018].
Kadir A. 2017. 80\% Kebutuhan Susu di Indonesia Masih Impor. Detik.com. https://finance.detik.com/industri/d3590894/80-kebutuhan-susu-di-indonesiamasih-impor [30 Oktober 2017].

Lupiyoadi R. 2001. Manajeman Pemasaran Jasa. Salemba. Depok

Martono N. 2012. Metode Penelitian Kunatitatif Analisis Isi dan Analisis Data Sekunder Edisi Revisi. PT. Raja Grafindo Persada. Jakarta.

Montung P, Sepang J dan Adare D. 2015. Pengaruh kualitas produk, kualitas layanan, dan persepsi harga terhadap pelanggan di Restoran Kawan Baru. Jurnal Berkala Ilmiah Efisiensi, 15 (5): 678-689. https://ejournal.unsrat.ac.id/index.php/jbie/ar ticle/view/10426/10010 [15 Oktober 2017].

Putri EV, Prasmatiwi FE dan Adawiyah R. 2015. Permintaan dan kepuasan konsumen rumahtangga dalam mengonsumsi susu bubuk di Bandar Lampung. JIIA, 4(3): 402408. http://jurnal.fp.unila.ac.id/index.php/ JIA/article/view/1090/995. [02 September 2018].

Rustanti N. 2015. Buku Ajar Ekonomi Pangan dan Gizi. Deepublish: CV. Bening Utama. Yogyakarta.

Sekretariat Jendral Pertanian. 2016. Outlook Susu Komoditas Pertanian Subsektor Peternakan. http://epublikasi.setjen.pertanian.go.id/arsipoutlook/70-outlook-peternakan/414-outlooksusu-2016. [23 November 2017].

Subroto MA. 2008. Real Food True Health. Agromedia. Jakarta.

Sufren dan Natanael Y. 2013. Mahir Menggunakan SPSS Secara Otodidak. PT Elex Media Komputindo. Jakarta.

Windarti T dan Ibrahim M. 2017. Pengaruh kualitas produk dan kualitas pelayanan terhadap kepuasan konsumen produk donat madu. Jom FISIP, 2 (4): 1-10. https://jom.unri.ac.id/index.php/JOMFSIP/ar ticle/view/15256/0. [31 Agustus 2018]. 